\title{
ANALYSIS OF THE APPLICATION OF BASIC TEACHING SKILLS AS PROFESSIONAL DEVELOPMENT EFFORTS FOR TEACHER IN ELEMENTARY SCHOOL
}

\section{Leny Retno Indriani, Kurnia Indrawati, Khafidatun Nafi'ah, Tri Saptuti Susiani}

Universitas Sebelas Maret

lenyretnoindriani@gmail.com

\section{Article History}

accepted 30/09/2018

approved $12 / 10 / 2018$

published $30 / 10 / 2018$

\section{Keywords}

basic teaching skills, teacher professionalism

\begin{abstract}
Educators or teachers are professionals, one of the tasks of the teacher is to plan and carry out the learning process. It is stated in the Republic of Indonesia Law on the Nasional Education System. In the process of learning, there are eight basic teaching skills that needs to be mastered by a teacher. Therefore, this study aims to describe the professionalism of teacher in the application of basic teaching skills. This research is conducted by using descriptive techniques. The data of this research are qualitative data that are gained by describing the observation sheets. The result showed that all skills have been implemented by the pre-service teachers of PGSD UNS, but there are several basic skills aspect that have not been fully implemented. This aspect is create variations. Therefore, all aspects of basic teaching skills include create variations need to be implemented to develop teacher the profesionalism.
\end{abstract}

Social, Humanities, and Education Studies (SHEs): Conference Series p-ISSN 2620-9284 https://jurnal.uns.ac.id/shes 


\section{PENDAHULUAN}

Pendidikan merupakan kebutuhan mendasar dalam pembangunan bangsa. Maju tidaknya suatu bangsa tergantung pada kualitas pendidikan yang ada pada bangsa tersebut. Jika pendidikan berkualitas baik, maka sangat besar kemungkinan bahwa negara tersebut akan mengalami kemajuan. Jika pendidikan berkualitas buruk, dapat dipastikan bahwa negara tersebut tidak akan mampu bersaing dengan negara lainnya.

Guru sebagai pendidik merupakan salah satu faktor penentu mutu pendidikan. Oleh karena itu, perlu sosok guru yang kompeten, bertanggung jawab, terampil, dan berdedikasi tinggi. Hal ini sesuai dengan pendapat Bhargava et al (2011:77) yang menyatakan bahwa faktor terpenting dalam pembelajaran adalah guru. Guru yang baik adalah guru yang memenuhi kompetensi guru sesuai dengan yang diharapkan.

Kompetensi guru merupakan kemampuan seorang guru dalam melaksanakan kewajibannya dengan layak dan penuh tanggung jawab. Berdasarkan Peraturan Menteri Pendidikan Nasional Republik Indonesia Nomor 16 tahun 2007 tentang Standar Kualifikasi Akademik dan Kompetensi Guru dikembangkan secara utuh dalam empat kompetensi meliputi kompetensi pedagogik, kompetensi kepribadian, kompetensi sosial dan kompetensi profesional yang di peroleh melalui pendidikan profesi. Kompetensi profesional merupakan kemampuan penguasaan materi pembelajaran secara luas dan mendalam yang memungkinkan membimbing peserta didik memenuhi standar kompetensi.

Saragih (2008) menyatakan bahwa kompetensi minimal seorang guru baru adalah menguasai keterampilan mengajar dalam hal membuka dan menutup pelajaran, bertanya, memberi penguatan, dan mengadakan variasi mengajar. Miarso (2008) menyatakan bahwa guru yang berkualitas atau yang berkualifikasi adalah yang memenuhi standar pendidik, menguasai materi/isi pelajaran sesuai dengan standar isi, menghayati dan melaksanakan proses pembelajaran sesuai dengan standar proses pembelajaran. Standar proses untuk satuan pendidikan dasar dan menengah mencakup perencanaan proses, pelaksanaan pembelajaran, penilaian hasil pembelajaran, dan pengawasan proses pembelajaran.

Usman (2006: 74) dalam Yunia: 2015 mengemukakan proses pembelajaran terdapat delapan keterampilan dasar mengajar yang perlu dikuasai oleh seorang guru yaitu sebaga berikut: keteramplan bertanya; keterampilan memberi penguatan; keterampilan mengadakan variasi; keterampilan menjelaskan; keterampilan membuka dan menutup pelajaran; keterampilan membimbing diskusi kelompok kecil; keterampilan mengelola kelas; keterampilan mengajar perorangan. Terdapat komponen-komponen keterampilan mengadakan variasi yaitu sebagai berikut:

1) Variasi dalam cara mengajar guru,

a. Penggunaan variasi suara, seperti dari keras menjadi lembut, tinggi menjadi rendah, cepat menjadi lambat, atau saat memberikan tekanan pada kata-kata tertentu.

b. Pemusatan perhatian siswa, pada hal-hal yang dianggap penting

c. Kesenyapan, adanya diam tiba-tiba yang disengaja saat guru menerangkan.

d. Mengadakan kontak pandang dan gerak, pandangan guru menjelajahi seluruh kelas dan melihat ke mata murid-murid.

e. Gerakan badan mimik, berupa ekspresi wajah guru, gerakan kepala, dan gerakan badan.

f. Pergantian posisi guru di dalam kelas dan gerak guru

2) Variasi dalam penggunaan media dan alat pengajaran,

a. Variasi alat, bahan yang dapat dilihat, seperti grafik, bagan, poster.

b. Variasi alat, bahan yang dapat didengar, seperti rekaman suara, dan musik.

c. Variasi alat, bahan yang dapat diraba, dimanipulasi, dan digerakkan. Seperti : patung, topeng, dan boneka. 
d. Variasi alat, bahan yang dapat dilihat, didengar, dan diraba. Seperti : film, televisi, radio, dan slide projector yang diiringi penjelasan guru.

3) Variasi pola interaksi dan kegiatan siswa,

a. Pola guru-murid :

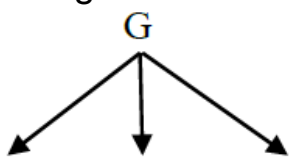

Komunikasi sebagai aksi (satu arah)

b. Pola guru-murid-guru :

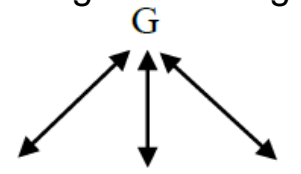

Ada balikan bagi guru, tidak ada interaksi

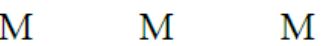

c. Pola guru-murid-murid :

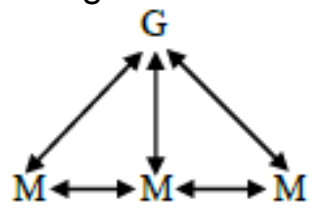
antarsiswa (komunikasi sebagai interaksi)

d. Pola guru-murid, murid-guru, murid-murid

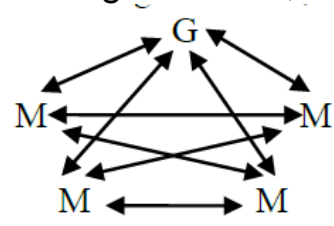

Ada balikan bagi guru, siswa saling belajar satu sama lain.

e. Pola melingkar

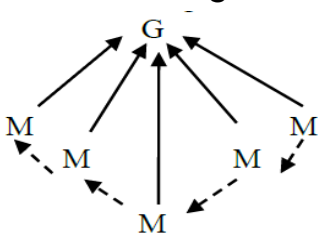

Interaksi optimal antara guru dengan murid dan antara murid dengan murid (multiarah)

Analisis keterampilan dasar mengajar dideskripsikan dalam tabel indikator sebagai berikut (Ambarwati, 2016) :

\begin{tabular}{|c|c|c|}
\hline No & Aspek & Indikator \\
\hline 1 & $\begin{array}{l}\text { Keterampilan membuka dan menutup } \\
\text { pembelajaran }\end{array}$ & $\begin{array}{ll}\text { - } & \text { Menarik perhatian } \\
\text { - } & \text { Menimbulkan motivasi } \\
\text { - } & \text { Memberi acuan } \\
\text { - } & \text { Membuat kaitan } \\
\text { - } & \text { Meninjau kembali } \\
\text { - } & \text { Penguasaan inti pelajaran } \\
\text { - } & \text { Mengevaluasi } \\
\text { - } & \text { Penilaian dan refleksi }\end{array}$ \\
\hline 2 & Keterampilan menjelaskan & $\begin{array}{l}\text { - } \quad \text { Penggunaan metode } \\
\text { - } \quad \text { Ketepatan materi } \\
\text { - } \quad \text { Penguasaan kompetensi }\end{array}$ \\
\hline
\end{tabular}


3

Keterampilan bertanya

4 Keterampilan mengadakan penguatan

$5 \quad$ Keterampilan mengadakan variasi

6 Keterampilan mengelola kelas

$7 \quad$ Keterampilan mengelola diskusi

8 Keterampilan mengajar perorangan
- Pertanyaan jelas dan singkat

- Pemberian acuan

- Pemindahan giliran

- Penyebaran

- Pemberian waktu berpikir

- Pemberian tuntunan

- Penguatan individu

- Penguatan terhadap kelompok

- Penguatan dengan segera

- Variasi penguatan

- Variasi dalam mengajar

- Variasi dalam penggunaan media pembelajaran

- Variasi dalam pola interaksi dan kegiatan siswa

- Bersikap tanggap

- Membagi pehatian

- Memusatkan perhatian kelompok

- Menuntut tanggung jawab siswa

- Memberikan petunjuk yang jelas

- Memusatkan perhatian

- Memperluas masalah

- Menganalisis pandangan peserta didik

- Meningkatkan pendapat

- Kesempatan berpartisipasi

- Menutup diskusi

- Mengorganisasikan kelas

- Membimbing belajar

- Memiliki perencanaan

- Tugas

- Berkomunikasi

- Pendekatan guru

Namun dalam kenyataannya sering di jumpai bahwa, beberapa keterampilan dasar mengajar tidak selalu di terapkan dalam proses pembelajaran. Salah satunya yaitu keterampilan mengadakan variasi. Berdasarkan hal tersebut peneliti tertarik melakukan pengamatan mengenai keterampilan dasar mengajar yang dilakukan oleh calon guru. Dalam hal ini, Mahasiswa PGSD sebagai calon guru yang nantinya akan terjun dalam dunia pendidikan harus memiliki kemampuan mengajar yang profesional. Yang mana seorang guru dikatakan profesional jika memiliki kemampuan yang baik dalam mengajar. Salah satunya menguasai keterampilan dasar mengajar. Semakin baik kemampuan yang kuasai oleh calon guru, semakin baik pula pendidikan yang akan terlaksana. 


\section{METODE}

Jenis penelitian ini adalah penelitian deskriptif dengan pendekatan kualitatif. Subyek dari penelitian ini terdiri dari empat mahasiswa angkatan 2015 program studi PGSD. Instrumen yang digunakan adalah lembar observasi keterampilan mengajar calon guru. Data yang dianalisis adalah hasil dari lembar observasi keterampilan dasar mengajar calon guru yang dideskripsikan. Sumber data pada penelitian ini adalah mahasiswa sebagai subyek penelitian.

Penelitian ini dilaksanakan di SDN 2 karangsari, Kecamatan Kebumen, Kabupaten Kebumen. Subyek penelitian ini adalah empat mahasiswa PGSD UNS angkatan 2015 yang sedang melakukan praktik magang 3. Teknik pengumpulan data dalam penelitian ini menggunakan metode observasi dan wawancara.

Analisis data yang digunakan dalam penelitian ini adalah teknik analisis data deksriptif kualitatif, yakni menggambarkan atau menyampaikan data menggunakan uraian naratif ataupun penggambaran dengan menggunakan kata-kata. Aspek yang dianalisis adalah keterampilan dasar mengajar yang dilaksanakan oleh calon guru dalam melaksanakan proses pembelajaran selama magang 3 di SDN 2 Karangsari.

\section{HASIL DAN PEMBAHASAN}

Berdasarkan observasi dan wawancara didapatkan hasil yang menunjukan bahwa mahasiswa calon guru sudah menerapkan delapan keterampilan dasar mengajar. Hal ini sesuai dengan pendapat Usman (2006: 74) dalam (Azizah: 2017) mengenai delapan keterampilan dasar mengajar yang perlu dikuasai oleh seorang guru dalam proses pembelajaran yaitu keterampilan bertanya; keterampilan memberi penguatan; keterampilan mengadakan variasi; keterampilan menjelaskan; keterampilan membuka dan menutup pelajaran; keterampilan membimbing diskusi kelompok kecil; keterampilan mengelola kelas; keterampilan mengajar perorangan. Berikut adalah hasil observasi dan wawancara yang dilaksanakan :

\section{Keterampilan Mengadakan Variasi}

Calon guru sekolah dasar yang terdiri dari empat subyek dalam mengadakan masih kurang baik. Pada indikator variasi cara mengajar meliputi suara, mimik dan gerak, kesenyapan, kontak pandang, perubahan posisi dan memusatkan perhatian siswa. Dalam pelaksanaanya guru sudah melakukan kontak pandang dengan siswa dan gerak yang dilakukan di kelas sudah bervariasi. Pada mimik dan gerak untuk memperjelas penyajian, calon guru sudah melaksanakan dengan baik. Namun untuk mengadakan kesenyapan, variasi suara, pemusatan perhatian siswa belum terlaksana dengan baik. Pada saat pembelajaran nada suara yang seharusnya pada hal-hal yang dianggap penting lebih ditekankan, namun pada hasil pengamatan ditemukan bahwa variasi nada suara terlalu monoton. Variasi volume suara yang digunakan oleh calon guru lebih dominan keras. Variasi kesenyapan yang meliputi melayangkan pandang dan memberikan waktu senyap / hening dalam pembicaraan masih belum ditemukan pada keempat subyek. Selanjutnya pada variasi memusatkan perhatian sudah dilakukan. Namun ketika pemusatan perhatian anak masih belum terpusat pada guru.

Pada indikator variasi dalam penggunaan media pembelajaran sudah tercapai tetapi pada kelas rendah yang berupa variasi alat dan bahan yang dapat diraba belum terlaksana pada subjek satu dan subyek dua. Sedangkan variasi alat bahan yang dapat dilihat, didengar, dan gabungan variasi alat dan bahan yang dapat dilihat, didengar dan diraba sudah terlaksana oleh semua subjek baik di kelas rendah maupun di kelas tinggi.

Pada indikator variasi dalam pola interaksi dan kegiatan siswa terdapat beberapa pola yang sudah dilaksanakan dengan baik yaitu pola guru-murid, pola guru-muridguru, dan pola guru-murid-murid. Mengenai pola interaksi guru-murid, murid-guru, murid-murid, belum terjadi. Begitu pula dengan pola interaksi melingkar belum terjadi. 
Kebanyakan guru lebih banyak menunjuk beberapa anak saja, jadi anak yang lain tidak mendapatkan giliran untuk mengemukakan pendapatnya.

\section{Keterampilan Membuka dan Menutup Pelajaran}

Calon guru sekolah dasar yang terdiri dari empat subyek sudah melaksankan keterampilan membuka dan menutup pelajaran. Indikator menarik perhatian sudah tercapai, indikator menimbulkan motivasi sudah tercapai, indikator memberi acuan sudah tercapai dan indikator membuat kaitan juga sudah muncul dalam pembelajaran yang dilakukan. Keterampilan menutup pembelajaran yang sudah dilaksanakan. Indikator meninjau kembali sudah dilaksanakan, indikator penguasaan inti pelajaran sudah dilaksanakan, keterampilan mengevaluasi sudah dilaksanaka, indikator penilaian dan refleksi sudah dilaksanakan.

Hasil penelitian menunjukan bahwa keterampilan membuka dan menutup pelajaran sudah dilaksanakan seluruhnya. Kesimpulan ini didasarkan dari hasil observasi dan wawancara yang menunjukan bahwa seluruh indikator dalam keterampilan membuka dan menutup pelajaran sudah di laksanakan oleh calon guru dalam pembelejaran di dalam kelas.

\section{Keterampilan menjelaskan}

Calon guru sekolah dasar yang terdiri dari empat subyek keterampilan menjelaskan yang baik. Indikator penggunaan metode sudah dilaksanakan, indikator ketepatan materi sudah di terapkan dan indikator penguasaan kompetensi sudah dilaksanakan

Hasil penelitian menunjukan bahwa keterampilan menjelaskan sudah dilaksankan seluruhnya. Kesimpulan ini didasarkan dari hasil wawancara dan observasi yang menunjukan bahwa seluruh indikator dalam keterampilan menjelaskan sudah dilaksanakan oleh calon guru dalam pembelajaran di dalam kelas.

\section{Keterampilan bertanya}

Calon guru sekolah dasar yang terdiri dari empat subyek sudah melaksanakan keterampilan bertanya namun hasilnya kurang optimal. Indikator pengungkapan pertanyaan secara jelas dan singkat sudah di laksanakan, indikator pemberian acuan sudah dilaksanakan, pemindahan giliran masih kurang dalam pelaksanakannya, indikator penyebaran masih kurang dalam pelaksanakan, indikator pemberian waktu berpikir sudah dilaksanakan dan indikator pemberian tuntunan sudah dilaksanakan.

Hasil penelitian menunjukan bahwa keterampilan bertanya kurang optimal. Kesimpulan ini didasarkan dari hasil wawancara dan observasi yang menunjukan bahwa sebagian besar indikator dalam keterampilan bertanya sudah dilaksanakan oleh calon guru dalam pembelejaran di dalam kelas.

\section{Keterampilan mengadakan penguatan}

Calon guru sekolah dasar yang terdiri dari empat subyek sudah melaksanakan keterampilan mengadakan penguatan secara keseluruhan. Indikator Penguatan terhadap siswa tertentu sudah dilaksanakan, indikator penguatan terhadap kelompok sudah dilaksanakan, indikator penguatan dengan segera sudah dilaksankan dan indikator variasi penguatan sudah dilaksanakan.

Hasil penelitian menunjukan bahwa keterampilan mengadakan penguatan sudah baik. kesimpulkan ini didasarkan dari hasil wawancara dan observasi yang menunjukan bahwa seluruh indikator keterampilan mengadakan penguatan sudah di laksanakan oleh calon guru dalam pembelajaran di dalam kelas.

\section{Keterampilan mengelola kelas}

Calon guru sekolah dasar yang terdiri dari empat subyek sudah melaksanakan keterampilan mengelola kelas. Indikator bersikap tanggap sudah dilaksanakan, indikator membagi perhatian sudah dilaksanakan, keterampilan memusatkan perhatian kelompok sudah dilaksanakan namun kurang berhasil, indikator menuntut tanggung jawab siswa sudah dilaksanakan dan indikator memberikan petunjuk yang jelas sudah dilaksanakan. 
Hasil penelitian menunjukan bahwa keterampilan mengelola kelas sudah terlaksana seluruhnya, hanya saja pada indikator memusatkan perhatian belum berhasil. Kesimpulkan didasarkan dari hasil wawancara dan obeservasi yang menunjukan bahwa sebagian indikator keterampilan mengelola kelas sudah dilaksanakan oleh calon guru dalam pembelajaran di dalam kelas.

\section{Keterampilan mengelola diskusi}

Calon guru sekolah dasar yang terdiri dari empat subyek sudah melaksanakan keterampilan mengelola diskusi secara keseluruhan. Indikator memusatkan perhatian sudah dilaksanakan, indikator memperluas masalah sudah dilaksanakan, keterampilan menganalisis pandangan peserta sudah dilaksanakan, indikator meningkatkan pendapat sudah dilaksanakan, indikator kesempatan berpartisipsi sudah dilaksanakan, dan indikator menutup diskusi sudah dilaksanakan.

Hasil penelitian menunjukan bahwa keterampilan mengelola diskusi sudah dilaksanakan Kesimpulkan didasarkan hasil wawancara dan obeservasi yang menunjukan bahwa seluruh indikator keterampilan mengelola diskusi sudah dilaksanakan oleh calon guru dalam pembelajaran di dalam kelas.

\section{Keterampilan mengajar perorangan}

Calon guru sekolah dasar yang terdiri dari empat subyek sudah melaksanakan keterampilan mengajar perorangan secara keseluruhan. Indikator mengorganisasikan kelas sudah dilaksanakan, indikator membimbing belajar sudah dilaksanakan, keterampilan memiliki perencanaan sudah dilaksanakan, indikator tugas sudah dilaksanakan, indikator berkomunikasi sudah dilaksanakan, dan indikator pendekatan guru sudah dilaksanakan.

Hasil penelitian menunjukan bahwa keterampilan mengajar perorangan sudah dilaksanakan. Kesimpulkan ini didasarkan dari hasil wawancara dan obeservasi yang menunjukan bahwa seluruh indikator keterampilan mengajar perorangan sudah dilaksanakan oleh calon guru dalam pembelajaran di dalam kelas.

\section{SIMPULAN}

Dari uraian hasil dan pembahasan diatas, didapatkan kesimpulan bahwa keterampilan dasar mengajar merupakan salah satu upaya yang dapat dilakukan untuk pengembangan profesionalisme guru. Guru di katakan profesional jika sudah memenuhi kompetensi guru. Salah satu bagian dalam kompetensi guru adalah keterampilan dasar mengajar.

Dalam keterampilan dasar mengajar yang dilaksanakan oleh calon guru sudah dilaksanakan seluruhnya namun terdapat beberapa indikator yang belum mendapatkan hasil optimal. Aspek keterampilan membuka dan menutup pelajaran sudah terlaksana, keterampilan menjelaskan sudah terlaksana, keterampilan bertanya sudah cukup baik namun indikator pemindahan giliran dan penyebaran masih kurang dalam pelaksanaannya, keterampilan memberikan penguatan sudah baik, keterampilan mengelola kelas sudah terlaksana namun pada indikator pemusatan perhatian masih belum berhasil, keterampilan mengelola diskusi sudah terlaksana, keterampilan mengajar perorangan sudah terlaksana, keterampilan mengadakan variasi sudah terlaksana namun pada indikator variasi alat dan bahan yang dapat diraba hanya dilaksanakan oleh subyek satu dan subyek dua.

Hasil penelitian ini diharapkan dapat digunakan sebagai masukan bagi calon guru maupun guru dalam meningkatkan kualitas pembelajaran di kelas. Selain itu, penelitian ini juga diharapkan dapat membantu calon guru dan guru sebagai masukan dalam upaya peningkatan profesionalisme guru untuk mencapai tujuan pendidikan yang lebih optimal. 
DAFTAR PUSTAKA

Ambarwati, Mika. (2016). Analisis Keterampilan Mengajar Calon Guru Pendidikan Matematika Pada Mata Kuliah Micro Teaching. Jurnal Pedagogia, Vol. 5, No. 1

Bhargava, A. \& Pathy,M. (2011). Perseption of student teachers about teaching competencies. Journal of Contemporary Research 1 (1)77.

Depdiknas.,2007 Nomor 16 tahun tentang Standar Kualifikasi Akademik dan Kompetensi Guru, Depdiknas : Jakarta

Miarso, Y. (2008). Peningkatan kualifikasi guru dalam persektif teknologi pendidikan. Jurnal Pendidikan Penabur 7 (10): 66-76.

Saragih, A.H. (2008). Kompetensi minimal seorang guru dalam mengajar. Jurnal tabularasa PPS UNIMED 5 (1) : 23-34

Yunia,Meta. 2015. Pengaruh Keterampilan Mengajar Terhadap Motivasi Belajar Siswa Sd Negeri Jatibarang Kidul 05 Kabupaten Brebes. Skripsi diterbitkan. Fakultas ilmu pendidikan Universitas Negeri Semarang 